\title{
PENGEMBANGAN BUKU BANTUAN DIRI UNTUK MEMBANTU REMAJA \\ MEMELIHARA IKATAN KELEKATAN (ATTACHMENT BOND) YANG ORANGTUANYA BERCERAI SMA SE-DKI JAKARTA
}

\author{
Susi Fitri ${ }^{1}$ \\ Annisa Kusumaningtyas ${ }^{2}$
}

\begin{abstract}
Abstrak
Penelitian ini bertujuan untuk menghasilkan suatu media berupa buku bantuan diri untuk membantu remaja SMA di DKI Jakarta yang orangtuanya bercerai memelihara ikatan kelekatan. Buku bantuan diri dapat digunakan secara individual maupun oleh guru bimbingan dan konseling dalam proses konseling. Buku bantuan diri yang dikembangkan terdiri dari tujuh bab. Bab 1 sampai dengan 4 merupakan pemahaman diri konseli mengenai perceraian dan perasaan peserta didik. Membantu peserta didik untuk menyadari, menerima, dan mengekpresikan perasaan. Pada bab 5 dan 6 merupakan treatment dalam buku. Membantu peserta didik memiliki harapan yang aman terhadap orangtua. Pada bab 7 yaitu mengenai pemeliharaan yang merupakan kesimpulan dan refleksi diri setelah merampungkan buku bantuan diri. Metode penelitian yang digunakan adalah Research and Development (RnD) model ADDIE (Analyze, Design, Develop, Implement, Evaluate). Tahapan model pengembangan yang dilakukan adalah analisis, desain, dan pengembangan. Alat pengumpulan data yang digunakan berupa angket dan pedoman wawancara. Penilaian media dilakukan oleh validator yang terdiri dari ahli media, ahli materi dan peserta didik. Dari hasil uji validasi tersebut diperoleh rata-rata persentase dengan validasi ahli media $93,26 \%$, validasi ahli materi $93,75 \%$, peserta didik $91,77 \%$, dan guru bimbingan dan konseling 92,04\%. Hasil pengembangan buku bantuan diri untuk memelihara ikatan kelekatan bagi remaja yang orangtuanya bercerai dikategorikan layak.

Kata Kunci : Ikatan Kelekatan (Attachment Bond), Buku Bantuan Diri, Model ADDIE, Perceraian
\end{abstract}

\begin{abstract}
This study aims to develop a media that is a self help book to help high school adolescents in DKI Jakarta maintain attachment bond after their parents' divorce. The book can be used individually or by school counselors in the counseling process. The book consists of seven chapters. Chapters 1 to 4 discuss student's selfunderstanding of the divorce and their feelings. They help students realize, accept, and express their feelings. While chapters 5 and 6 are about treatments. They help students have secure expectancies to their parents. Chapter 7 is about self maintenance which is a conclusion and a self reflection after completing a psychological well-being. The method is Research and Development (RnD) with
\end{abstract}

\footnotetext{
${ }^{1}$ Universitas Negeri Jakarta, susi.fitri@unj.ac.id

${ }^{2}$ Universitas Negeri Jakarta, mail.annisakusumaningtyas@gmail.com
} 


\begin{abstract}
ADDIE model (Analyze, Design, Develop, Implement, Evaluate). The stages of the development model are analysis, design, and development. The technique of data collections is utilizing forms of questionnaires and interview. The evaluation of media was done by validators from the expert of media, the expert of material, students, and school counselors. Based on the validation test, it was obtained that the average percentage $93.75 \%$ of media expert, $93.75 \%$ of material expert, $91.77 \%$ of students, and $92.04 \%$ of school counselors. The result of the development of self help book is to help adolescents maintain attachment bond after their parents' divorce was categorized as appropriate.
\end{abstract}

Keywords: Attachment Bond, Self Help Book, ADDIE Model, Divorce

\section{PENDAHULUAN}

Berdasarkan data yang dihimpun Badan Pusat Statistik (BPS) pada tahun 2012 hingga 2015 menunjukan bahwa angka perceraian dari tahun ke tahun mengalami peningkatan. Tercatat pada tahun 2012 persentase angka perceraian mencapai $15.13 \%$ (346.480 kasus), 2013 sebanyak $14.67 \%$ (324.427), 2014 sebanyak $16.30 \%$ (344.237), dan tahun 2015 sebanyak 17.73\% (347.256 kasus).

Dalam teori kelekatan (attachment), perpisahan merupakan sebuah ancaman yang mendasar terhadap psychological wellbeing anak (Bowlby, 1973). Venta, Shmueli-Goetz, dan Sharp (2014) menjelaskan bahwa keamanan kelekatan (attachment security) merupakan hal yang penting terhadap kesehatan psikologis (well being) remaja. Dengan kata lain perceraian dapat terlihat sebagai sebuah ancaman terhadap keamanan (security). Bahaya dari perpisahan sebagai akibat dari pemahaman bahwa orangtuanya tidak dapat dijangkau. Perpisahan memberikan persepsi terhadap ketersediaan, dan responsifitas dari figur kelekatan atau dalam hal ini adalah orangtua.

Bowlby (1973) menjelaskan perasaan yang muncul setelah perpisahan diantaranya adalah ketakutan (fear), kemarahan (angry protest), usaha-usaha yang nekat (desperate effort), kesedihan (sadness), dan putus asa (despair). Berpisah dengan orangtua juga dapat diartikan sebagai ancaman terhadap bahaya yang akan mengaktifkan fear system dan sistem perilaku kelekatan (attachment behavioral system). Perilaku yang dapat mendekatkan anak dengan figur kelekatan dapat berupa perilaku yang adaptif maupun maladaptif. Hal tersebut yang dapat menjelaskan munculnya internalizing problem behavior dan externalizing problem behavior (Vaughn \& Bost, 2016).

Berdasarkan studi pendahuluan yang dilakukan pada 27 remaja SMA di DKI Jakarta yang orangtuanya bercerai dengan menggunakan angket. Hasil yang didapatkan yaitu $37 \% \quad(10$ orang) orangtuanya bercerai ketika responden berusia 1-8 tahun. Sedangkan 63\% (17 orang) orangtuanya bercerai ketika berusia 10-17 tahun atau pada masa remaja. Selain itu, 70\% (19 orang) mengungkapkan bahwa perceraian adalah hal yang mengancam berkaitan dengan perasaan aman (security). Sebanyak 59\% (16 orang) tidak dapat menerima perceraian orangtua mereka. Alasan mereka tidak menerima perceraian tersebut diantaranya $21 \%$ (4 orang) merasa iri, cemburu pada teman yang memiliki orangtua utuh; $10 \%$ (2 orang) merasa orangtua tidak lengkap; $10 \%$ (2 orang) merasa kurang kasih sayang; $16 \%$ mengaku sulit berpisah dengan orangtua; $10 \%$ menjelaskan bahwa orangtua yang tidak tinggal bersama (ayah) tidak membiayai kehidupan anak setelah perceraian; 5\% (1 orang) kehilangan komunikasi dengan orangtua yang tidak tinggal bersama; 5\% (1 orang) terbiasa tinggal serumah dengan kedua orangtua; $5 \%$ (1 orang) menyatakan bahwa perceraian tidak memikirkan masa depan anak; 5\% (1 orang) tertekan dengan 
orangtua tiri; $5 \%$ (1 orang) sulit bertemu orangtua; $5 \%$ (1 orang) merasa sakit hati.

Persentase sebanyak $41 \%$ (11 orang) dapat menerima perceraian orangtuanya dan ada beberapa alasan anak menerima perceraian orangtuanya. Diantaranya adalah $10 \%$ (1 orang) menyatakan bahwa menerima perceraian orangtuanya karena menganggap itu adalah masalah orangtua, responden tidak merasakan apa-apa (numb); 55\% (6 orang) menganggap bahwa perceraian adalah jalan terbaik agar salah satu orangtua tidak semakin tersakiti, 27\% (3 orang) menerima karena merasa tidak bisa berbuat apa-apa atas perceraian orangtua. Reaksi emosi yang muncul setelah keputusan perceraian digambarkan dengan 46\% (13 orang) merasa sedih, 32\% (9 orang) kaget, $36 \%$ (10 orang) marah, $11 \%$ (3 orang) bebas, $18 \%$ (5 orang) tidak merasakan apa-apa, $25 \%$ (7 orang) lainnya. Selain itu, 26\% (7 orang) merasa malu atas perceraian yang terjadi pada kedua orangtuanya. Alasannya beragam diantaranya adalah menganggap bahwa perceraian adalah hal yang membuat malu dan sedih, merasa tidak memiliki kebahagiaan seperti teman yang lain, malu pada teman jika ditanya mengenai orangtua, orangtua teman yang lain tidak ada yang bercerai, teman-teman memiliki dua orangtua sehingga malu jika orangtua bercerai, merasa kondisinya berbeda dari orang lain, takut jika dirinya dituduh sebagai penyebab perceraian orangtuanya.

Data lain yang penting berkaitan dengan aksesibilitas dan responsifitas orangtua setelah perceraian. Hasil menunjukan bahwa 48\% (13 orang) merasa takut akan diabaikan oleh orangtua, $44 \%$ (12 orang) takut diabaikan oleh orangtua yang tidak tinggal bersama, dan 39\% merasa diabaikan oleh orangtua yang tidak tinggal bersama (noncustodial parent). Selanjutnya, sejumlah $55 \%$ (15 orang) merindukan tinggal bersama kedua orangtua, $15 \%$ (3 orang) merasa bersalah pada orangtua yang tidak tinggal bersama, $15 \%$ (3 orang) merasa senang dan aman, $15 \%$ (3 orang) lainnya memilih lainnya.
Berdasarkan hasil wawancara dengan peserta didik maka didapatkan kesimpulan bahwa perceraian memberikan beberapa dampak diantaranya pada bidang akademik, sosial, pribadi, dan emosi. Dampak akademik yang muncul diantaranya adalah sulit berkonsentrasi dan fokus belajar sehingga berdampak pada penurunan nilai akademik disekolah. Dampak emosi yang muncul adalah distress, merasakan kesedihan yang mendalam, mudah marah, dan membenci orangtuanya (terutama ibu), merasa hidup menjadi kacau. Dampak pada diri peserta didik yang muncul pada bidang pribadi yaitu sulit mengendalikan emosi, sering menangis dan menarik diri dari lingkungan, jarang bercerita mengenai kehidupannya. Dampak perilaku diantaranya adalah munculnya perilaku maladptif untuk menghilangkan berbagai emosi yang ditimbulkan dari perceraian yaitu dengan merokok, malas belajar karena sulit berkonsentrasi, sering memikirkan orangtua yang tidak tinggal bersama, dan sering menangis di kamar karena merasa sangat sedih atas perceraian orangtua.

Dari empat responden, 50\% mengaku masih merasakan perasaan kesedihan, kemarahan, ketakutan hingga kini dan 50\% lagi sudah tidak merasakannya lagi. Dalam menghadapi masalah perceraian orangtuanya responden merasa bingung, hanya berdoa, sabar, dan tidak melakukan apapun. Ada $80 \%$ (4 orang) menyatakan terdapat perubahan komunikasi dengan orangtua setelah perceraian terjadi. Perubahan perhatian orangtua sebelum dan sesudah perceraian dirasakan oleh $60 \%$ (3 orang) responden. Selanjutnya, $100 \%$ (5 orang) tidak dapat mengungkapkan perasaan terhadap kesulitan yang dihadapi setelah perpisahan dengan orangtua terjadi. Salah satu responden $\mathrm{R}$ (15 tahun) mengungkapkan "Tidak, sangat sulit untuk menceritakan tidak ada kata-kata yang bisa mendeskripsikan perasaan saya setelah orangtua berpisah".

Berdasarkan wawancara dengan guru BK diketahui bahwa dampak perceraian terhadap peserta didik yaitu masalah 
akademik, masalah sosial dengan temantemannya, dan perkembangan. Nilai peserta didik cenderung turun yang diakibatkan oleh seringnya tidak masuk kelas. Hal itu pula menyebabkan dia jarang bertemu dengan teman-teman kelasnya dan hanya akrab dengan beberapa orang saja, perubahan sikap dan kebiasaan yang maladaptif seperti perilaku yang cenderung cari perhatian, bolos, melamun, dan berkurangnya motivasi belajar yang berpengaruh terhadap kondisi akademik peserta didik. Selain itu, hubungan sosial anak yang orangtuanya bercerai di sekolahnya cenderung suka menyendiri, serta merasa kurang percaya diri. Kondisi emosi anak yang orangtuanya baru bercerai biasanya masih meluap-luap, tinggi karna belum terbiasa dengan kondisinya, dan biasanya cenderung lebih sensitif.

Gambaran masalah peserta didik yang orangtuanya bercerai biasanya berkaitan dengan kehadiran dikelas, bolos, serta motivasi belajar rendah. Guru BK pernah menangani kasus dimana peserta didik yang orangtuanya bercerai disebabkan oleh salah satu orangtua (ayah) berselingkuh dan sangat galak terhadap keluarganya. Jadi, siswa tersebut hanya diurusi oleh ibunya yang juga membiayai kehidupannya. Terdapat kasus lain juga dimana anak kehilangan kontak dengan orangtua yang tidak tinggal bersama dan ada pula yang mengalami trauma.

Cara penanganan mereka biasanya dengan cara pemanggilan peserta didik keruang BK atau peserta didik datang ke ruang BK lalu dilakukan konseling individu. Guru BK menangani kasus tersebut berbeda dengan kasus lainnya, dan biasanya untuk hal-hal traumatis dilakukan alih tangan kasus pada psikolog

Hasil studi pendahuluan menunjukan bahwa perceraian merupakan sebuah peristiwa yang dapat mengancam keamanan remaja. Perasaan aman dan tidak aman memberikan persepsi mengenai ketersediaan dan responsifitas figur kelekatan. Reaksi emosi dan perilaku yang muncul beragam yang merupakan cara untuk menjangkau figur kelekatan. Diantaranya adalah perasaan sedih, marah, kecewa, benci, malu, bahkan iri dan cemburu pada teman dengan keluarga yang tidak bercerai. Selain itu juga berpengaruh terhadap berbagai aspek kehidupan anak baik sosial, akademik, maupun pribadi.

Ikatan kelekatan (attachment bond) adalah sebuah ikatan antara individu dengan figure kelekatan (attachment figure), sebuah ikatan afeksional (affectional bond) yang melibatkan sistem perilaku kelekatan (attachment behavioral system) (Prior \& Glaser, 2006). Ikatan kelekatan berkembang dengan pesat dan cenderung bertahan lama. Ikatan tetap bertahan dan memainkan peran besar dalam menentukan hubungan sosial orang dewasa (Bowlby, 1982). Menurut Bowbly (Vaughn \& Bost, 2016) salah satu cara agar individu untuk merasakan keamanan adalah dengan tetap memelihara ikatan kelekatan (attachment bond) dengan pengasuh (caregiver) yang mudah didatangi dan responsif .

Malchiodi dan Gruenberg mengemukakan bahwa bibliotherapy adalah salah satu bentuk intervensi yang efektif jika digunakan untuk menangani anak yang mengalami pengalaman trauma, anak yang berduka karena kehilangan, berusaha keras bertahan karena perceraian, atau memulihkan diri dari pelecehan atau pengabaian (Malchiodi, 2015). Sebuah strategi yang mungkin dapat digunakan membantu anak dengan perceraian adalah penggunaan bibliotherapy (Kramer \& Smith, 1998).

Penggunaan buku bantuan diri (psychological well-being) sudah digunakan untuk bibliotherapy selama bertahun-tahun dan sekarang dapat disarankan untuk memberikan terapi psikologis bagi orangorang yang mengalami kesulitan emosional dan psikologis (Dublin City Council, 2011). Membaca buku bantuan diri dengan masalah yang spesifik cenderung sangat membantu untuk orang-orang dengan masalah tertentu. Selain itu, buku bantuan diri memiliki korelasi positif dengan beberapa topik tertentu diantaranya adalah topik keluarga 
berkorelasi positif, intimimasi berkorelasi sangat positif, kesehatan jiwa berkorelasi sangat positif (Bergsma, 2008).

Pada studi pendahuluan yang dilakukan, tiga responden dari lima responden $(60 \%)$ tertarik dengan buku bantuan diri untuk membantu memelihara hubungan setelah perceraian, satu orang $(20 \%)$ tidak terlalu, satu orang $(20 \%)$ tidak. Alasan responden yang tidak tertarik dikarenakan responden merasa hubungan dengan orangtuanya seperti anak yang tidak bercerai, tetapi ia membutuhkan buku yang membantunya menghadapi trauma dengan keluarga ayah. Sedangkan satu orang yang tidak terlalu tertarik mengungkapkan tidak begitu senang membaca buku kecuali cerita di wattpadd (Wattpad adalah layanan situs web dan aplikasi telepon pintar yang memungkinkan penggunanya untuk membaca ataupun mengirimkan karya dalam bentuk artikel, cerita pendek, novel, puisi, atau sejenisnya).

Buku bantuan diri akan berisi mengenai asesmen, treatment dan penggunaannya dalam bibliotherapy. Konten-konten yang menurut responden penting diantaranya adalah cara menghadapi trauma (untuk responden yang menginginkan buku bantuan diri untuk menghadapi trauma), cara menjaga hubungan yang baik, sikap yang harus dimiliki, hal yang harus dilakukan agar hubungan baik, cara membangun keharmonisan walaupun sudah berpisah, cara menghadapi perceraian. Ukuran buku yang disarankan responden bervariatif ada yang menginginkan berukuran seperti novel, buku tulis, dan kecil saja. Buku diharapkan menggunakan warna yang netral, bahasa yang mudah dipahami, santai dan tidak terlalu berat, desain buku sederhana, serta ilustrasi secukupnya. Berdasarkan hasil wawancara, guru Bk juga mengungkapkan bahwa pengembangan buku bantuan diri untuk anak-anak yang orangtuanya bercerai akan membantu proses bantuan pada peserta didik.

Pengembangan buku bantuan diri dapat digunakan untuk membantu anak yang orangtuanya bercerai. Buku tersebut dapat membantu remaja memelihara ikatan kelakatan dengan orangtua mereka dan berperan dalam perasaan aman. Dengan buku bantuan diri untuk memelihara ikatan kelekatan maka anak akan memiliki coping strategi dalam menghadapi perceraian, persepsi positif terhadap ketersediaan orangtua (caregiver), dan memelihara hubungan.

\section{PERCERAIAN}

Ahiaoma (2013) mengungkapkan bahwa perceraian adalah sebuah cara hukum untuk memutuskan pernikahan diantara dua orang. Pemisahan dan perceraian dikaitkan dengan emosi yang membangkitkan hati, kesedihan yang tak terkatakan, depresi, kecemasan dan lain sebagainya. Ningrum (2013) mengungkapkan bahwa perceraian merupakan titik puncak dari pengumpulan berbagai permasalahan yang menumpuk beberapa waktu sebelumnya dan jalan terakhir yang harus ditempuh ketika hubungan perkawinan itu sudah tidak dapat dipertahankan lagi. Selanjutnya, terdapat beberapa konsekuensi dari perpisahan dan perceraian, diantaranya adalah merubah gaya hidup dan tradisi keluarga, merubah keadaan ekonomi dan status finansial keluarga, psikologi anak, sosial serta perkembangan pendidikan, pasangan menghadapi banyak hal seperti perasaan tidak aman (insecurity), depresi, trauma psikologis dan emosional (Ahiaoma, 2013). Dagun (Ningrum, 2013) yang menyatakan bahwa kasus perceraian menimbulkan stres dan menimbulkan perubahan fisik, juga mental, keadaan ini dialami oleh semua anggota keluarga, ayah, ibu, dan anak. Berbagai perasaan yang mungkin dialami oleh anak seperti menyalahkan diri sendiri, merasa tanggung jawab meningkat, menyalahkan orangtua, takut untuk diabaikan. Penelitian yang dilakukan oleh Ahiaoma (2013) menunjukan bahwa terdapat hubungan antara perpisahan orangtua dengan akademik remaja. orang tua yang bercerai dan lingkungan.

Selain itu, Jensen (Harsanti \& Verasari, 2013) berpendapat bahwa perceraian orang tua mempunyai dampak terhadap anak yang 
negatif yang dapat merugikan diri sendiri dan orang lain, seperti merokok, memakai narkoba, meminum-minuman keras, seks bebas, hingga mengingkari status anak sebagai pelajar dengan cara membolos.

Hal tersebut mungkin berkaitan dengan temuan lain yang menyatakan bahwa perceraian orang tua berdampak buruk terhadap kemampuan untuk mencintai dan dicintai dalam hubungan yang bertahan lama dan berkomitmen (Mustonen, Huurre, Kiviruusu, Haukkala, \& Aro, 2011). Dari pengalaman perceraian mereka, anak dari segala usia mendapatkan sebuah kesimpulan yang menakuti mereka bahwa hubungan personal merupakan hal yang tidak dapat dipercaya/diandalkan, karena bahkan hubungan keluarga yang paling dekat pun tidak dapat diharapkan untuk tetap dipegang teguh (Wallerstein \& Lewis, 2004).

\section{KELEKATAN}

Kelekatan dicatat sebagai kecenderungan untuk pencarian kedekatan, hal tersebut merupakan ikatan afeksional yang kuat antara individu dengan individu lain (Rice, 1990). Lebih lanjut, Prior dan Glaser (2006) menjelaskan bahwa kelekatan merupakan sebuah keterikatan antara seorang individu dengan figur kelekatannya. Ainsworth, Blehar, Waters, dan Wall (2015) mengungkapkan bahwa kelekatan dapat didefinisikan sebagai ikatan afeksional antara satu orang dengan orang spesifik lain, sebuah ikatan yang mengikat mereka bersama dalam jarak dan bertahan seiring berjalannya waktu. Kelekatan beroperasi melalui sistem perilaku kelekatan (attachment behavioral system). Ainsworth dan Bell (1970) menjelaskan bahwa kelekatan tidak terjadi bersamaan dengan perilaku kelekatan (attachment behavior). Perilaku kelekatan ditimbulkan oleh situasi yang stressful yang mana kedekatan dengan figur kelekatan menjadi penting (Rice, 1990). Perilaku kelekatan dapat ditingkatkan atau dikurangi oleh kondisi-lingkungan dan intraorganismik. Perilaku kelekatan dapat ditingkatkan oleh situasi yang dianggap sebagai ancaman, baik itu adalah bahaya dari luar atau bahaya yang aktual bahkan perpisahan dengan figur kelekatan.

\section{IKATAN KELEKATAN}

Bonding adalah proses pembentukan kelekatan. Bonding adalah terminologi yang digunakan ketika penempelan (gluing) satu objek ke objek yang lain. Bonding menggunakan "lem emosi" kita untuk terhubung dengan orang lain. Bonding melibatkan seperangkat perilaku yang akan membantu untuk mengarah pada hubungan emosional (Perry, 2001). Ikatan kelekatan berkaitan dengan orang yang spesifik dan melibatkan banyak kenangan dan perasaan yang unik terhadap sejarah interaksi dengan orang khusus (Vaughn \& Bost, 2016). Kehadiran dari ikatan antara anak dengan figur kelekatan, sekali dibentuk, akan terus berlanjut meskipun terjadi perpisahan (Ainsworth et al., 2015). Perry (2001) menyatakan bahwa kelekatan memiliki beberapa elemen kunci diantaranya adalah : 1) ikatan kelekatan merupakan hubungan emosi yang bertahan (enduring) dengan orang spesifik, 2) hubungan membawa keamanan, kenyamanan, ketenangan dan kebahagiaan, 3) kehilangan atau ancaman dari kehilangan seseorang menimbulkan distress yang intens.

Gangguan kelekatan (attachment disruptions) didefinisikan sebagai ancaman yang berat dan berkepanjangan terhadap ketersediaan atau responsifitas pengasuh (caregiver) yang menciptakan ketakutan dan ketidakyakinan terhadap ketersediaan pengasuh atau kapasitas untuk merespon dalam momen yang berbahaya (Kobak, Zajac, \& Madsen, 2016). Padahal, ketika seorang anak atau orang dewasa mengalami sebuah ketakutan tetapi percaya bahwa figur kelekatan tersedia dan responsif, akan terdapat sebuah harapan terhadap pertolongan dan dukungan (Johnson, 2002).

Setiap individu membangun working models tentang dunia dan dirinya sendiri, dengan bantuan yang ia anggap peristiwa, meramalkan masa depan, dan membangunnya (Bowlby, 1973). Model kerja internal dari keterikatan adalah 
seperangkat ekspektasi yang diinternalisasi tentang diri dan orang lain yang dianggap berasal dari sejarah hubungan seseorang, dan untuk mempengaruhi persepsi seseorang dan perilaku dalam hubungan selanjutnya (Bretherton, 1990). Working models atau harapan terhadap ketersediaan dan responsifitas dari figur kelekatan akan membuat individu untuk mengadaptasi komunikasi dengan caregiver untuk memelihara ikatan kelelekatan (Kobak et al., 2016). Ketika jalur komunikasi tertutup atau terpotong, anak yang lebih tua atau orang dewasa dapat menganggap bahwa perpisahan fisik merupakan ancaman yang kuat untuk memelihara ikatan kelekatan (Vaughn \& Bost, 2016). Dalam volume perpisahan Bowlby (1973) mengarahkan perhatian pada pentingnya komunikasi terbuka dalam memelihara ikatan kelekatan. Bowlby menjelaskan bagaimana senyuman dan vokalisasi cenderung untuk menarik pengasuh pada bayi untuk dekat dengannya. Menangis dapat dijelaskan dengan "Datanglah, aku sangat membutuhkanmu". Tersenyum dan vokalisasi dapat diinterpretasikan sebagai "Tetaplah denganku, aku nyaman dengan keberadaanmu!". Ekspresi wajah dan gestur, dan vokalisasi mulai berubah pada tahap awal bahasa. Tipe interaksi dukungan komunikasi dengan figur kelekatan berlanjut untuk memelihara ikatan kelekatan (Ainsworth et al., 2015). Cara yang dapat digunakan untuk memelihara ikatan kelekatan adalah dengan adanya komunikasi yang terbuka. Pada hubungan yang aman (secure) sinyal saling diakui, mengizinkan untuk adanya informasi emosi yang terbuka antar individu. Internal working models terhadap diri dan orang lain dalam hubungan dapat menjadi kompleks dan secara mudah terbaharui (Bretherton, 1990). Attachmentrelated emotion dapat memfasilitasi atau menghancurkan komunikasi yang terbuka (Vaughn \& Bost, 2016). Kapasitas untuk mengkomunikasikan emosi yang rentan dan kebutuhan kelekatan akan sangat berguna untuk mendapatkan kenyamanan dan perlindungan dari alternatif caregivers atau memberikan tanda kebutuhan individu untuk mengembalikan kepercayaan pada hubungan yang terganggu (Kobak et al., 2016). Ketika ancaman terhadap ketersediaan partner dikomunikasikan secara terbuka, level konflik yang tinggi dan pelepasan ikatan dapat diperkecil. Selain itu, penyesuaian emosi (emotional attainment), responsifitas, serta menghadapi "bahaya", bersama akan menguatkan ikatan kelekatan yang aman (Johnson, 2002).

\section{KELEKATAN DAN PERCERAIAN}

Bowlby (Bowlby, 1973) mengusulkan bahwa fear system diaktifkan oleh tanda bahaya yang "natural", termasuk sesuatu yang asing/tidak biasa, stimulasi perubahan secara mendadak,ketinggian dan kesendirian. Bowbly mencatat bahwa fear system biasanya akan teraktivasi dalam gabungan beberapa situasi yang menakutkan, artinya terdapat beberapa tanda bahaya.

Dalam situasi dengan sedikit konflik yang ekstrem, orang tua yang saling melepaskan emosi satu sama lain dan memutuskan untuk berpisah atau bercerai dapat menimbulkan ketakutan pada anak bahwa orang tua juga akan memutuskan untuk meninggalkan anak tersebut (Vaughn $\&$ Bost, 2016). Perceraian merupakan salah satu gangguan dalam hubungan kelekatan (Vaughn \& Bost, 2016). Perceraian dapat memberikan persepi mengenai terbatasnya akses kepada figure kelekatan (attachment figure). Jelas bahwa perpisahan dan kehilangan memang menyakitkan dan menyedihkan, dan jika tidak terselesaikan mungkin akan meninggalkan sekuel emosi yang berkelanjutan (Prior \& Glaser, 2006). Bowlby (Ainsworth et al., 2015) menekankan pentingnya ketika peristiwa yang menakutkan muncul untuk bersama dengan orang yang dipercaya. Figur kelekatan adalah orang yang paling dapat dipercaya. Ketakutan untuk berpisah dengan figur kelekatan, tetapi "perpisahan" tidak bisa didefinisikan secara sederhana dengan ketidakhadiran figur. Hal yang paling penting adalah ketersediaan (availability) 
dari figur. Yaitu ketika figur dinilai tidak dapat dijangkau dan tidak responsif maka distress karena perpisahan (kedukaan) akan muncul, dan antisipasi dari kejadian semacam ini meningkatkan kecemasan. Anak yang mulai tumbuh dewasa dapat meningkatkan periode perpisahan dengan figur kelekatan tanpa distress. Peningkatan kemampuan kognitif mampu membuat anak memahami keadaan perpisahan, dan memiliki harapan bahwa figur kelekatan akan segera kembali, walaupun beberapa perpisahan yang traumatik membuat mereka meragukan bahwa figur kelekatan akan kembali (Ainsworth et al., 2015).

Bowlby mencatat bahwa perasaan aman didapatkan dengan menjaga kelekatan dengan pengasuh yang mudah dijangkau dan responsif. Dengan memelihara ikatan kelekatan maka individu dapat memiliki persepsi terhadap kepercayaan pada ketersediaan dan responsifitas dari figure kelekatan (Vaughn \& Bost, 2016).

\section{FASE PADA PERPISAHAN}

Emosi yang berbeda menyertai penilaian anak yang mengubah ketersediaan orang tua dan memainkan peran sentral dalam mengatur respons perilaku anak. Pemisahan distress dihasilkan dari penilaian bahwa orang tua tidak dapat dijangkau. Ancaman yang dirasakan terhadap aksesibilitas orang tua ini mengaktifkan sistem keterikatan (attachment system) dan memotivasi seorang anak untuk membangun kembali kontak dengan figur kelekatan (Vaughn \& Bost, 2016).

Robertson dan Bowbly (1973) mengidentifikasi tiga fase yang dialami individu dalam menghadapi perpisahan yaitu protes (protest), keputusasaan (despair), dan pelepasan (detachment). Bukti lebih lanjut untuk fase perpisahan berasal dari deskripsi yang diberikan oleh Heinicke dan Westheimer (1966).

Fase pertama adalah protes (protest) yang muncul mulai saat orangtua bersiap untuk berpisah. Selama fase ini, emosi dominan yang muncul adalah ketakutan, kemarahan, dan distress. Reaksi emosional yang menyertai penilaian terhadap ancaman termasuk didalamnya adalah ketakutan dan kemarahan (Vaughn \& Bost, 2016). Setelah perpisahan terjadi maka muncul kesedihan (pada anak-anak biasanya termanifestasikan dengan menangis), ketakutan, dan kemarahan. Mereka berusaha untuk menjangkau figur kelekatan (Bowlby, 1973).

Fase kedua adalah keputusasaan (despair), ditandai dengan perilaku meningkatnya keputusasaan terhadap kembalinya figur kelekatan (attachment figure). Bowbly (1973) menginterpretasikan fase ini mirip dengan kedukaan mendalam, ketika anak menginterpretasikan perpisahan sebagai kehilangan dari figur kelakatan (Vaughn \& Bost, 2016).

Mengurangi aktivitas dan menarik diri merupakan salah satu dari tanda tahap ini. Kesedihan yang disertai dengan menarik diri. Salah satu tanda dalam tahap ini adalah menarik diri dan mengurangi aktivitas. Pada anak-anak mereka menolak untuk ditenangkan atau didekati oleh orang lain (Bowlby, 1973).

Perubahan aktif anak terhadap lingkungan menandai fase akhir, pelepasan (detachment). Sebagai salah satu usaha awal untuk membangun kembali kontak yang gagal dan harapan anak terhadap bersatu kembali (reuni) dikecewakan, dia menilai kembali situasi, ketakutan dan usaha-usaha kemarahan untuk menyatukan kembali justru membawa pada kesedihan. Keputusasaan menyertai pengakuan bahwa protes tidak akan berhasil dalam membangun kembali kontak dengan orang tua (Vaughn \& Bost, 2016).

Pada fase terakhir, anak tidak lagi menolak pengasuh alternatif, dan beberapa anak bahkan menunjukan kebahagiaan dan kehilangan ketika ditinggalkan. Anak sudah mulai untuk mencari respon yang meyakinkan dan penuh kasih sayang dari orang lain (Bowlby, 1973). Keputusasaan yang berkepanjangan dan kegagalan untuk 
membangun kembali kontak, meninggalkan anak dalam keadaan yang tidak tertahankan, anak tersebut mungkin berusaha mengurangi rasa sakit ini dengan secara defensif tidak termasuk pemikiran, perasaan, dan kenangan tentang orang tua yang tidak hadir. Pelepasan bertahan (defensive detachment) menjadi satusatunya alat yang tersedia untuk mengatasi tekanan berat yang dialami anak (Vaughn \& Bost, 2016). Rheingold and Eckerman (Ainsworth et al., 2015) menggunakan terminologi "detachment" mengacu pada kesediaan anak untuk berpisah dari ibunya untuk memasuki dan menjelajahi ruang yang tidak.

\section{BIBLIOTHERAPI DAN BUKU BANTUAN DIRI}

Biblioterapi berasal dari bahasa Yunani yaitu buku (biblio) dan terapi (therapeia), dan telah digunakan sebagai metode terapeutik sejak Yunani kuno ketika pintu perpustakaan di Thebes dibaca "Tempat Penyembuhan Jiwa" (Pardeck, 1998). Menurut Orton (Campbell \& Smith, 2003) tujuan biblioterapi dari waktu ke waktu adalah untuk (a) memberikan informasi, (b) menghasilkan wawasan, (c) merangsang diskusi, (d) menciptakan kesadaran akan masalah orang lain, (e) memberikan solusi terhadap masalah, dan (f) memecahkan masalah masalah setelah terminasi. Tujuan ini merupakan hasil yang diinginkan psikoterapi dengan metode apapun; Namun, self-help program secara historis tidak dipandang sebagai pengobatan psikologis yang sah. Biblioterapi adalah penggunaan buku dalam konseling untuk mendukung perubahan pada diri klien (Campbell \& Smith, 2003).

Buku bantuan diri memiliki peranan penting terhadap materi yang digunakan di biblioterapi (Norcross, 2000). Lebih dari $60 \%$ konselor Kanada mengungkapkan bahwa mereka sering menggunakan bukubantuan diri (psychological well-being) dengan klien mereka (Adams \& Pitre, 2000).
Keuntungan dari penggunaan intervensi berbasis bantuan diri adalah tidak terdapat perbedaan signifikan ditemukan antara akhir treatment dan tindak lanjut, data menyebutkan bahwa menggunakan intervensi bantuan diri secara umum dapat menjaga peningkatan dari treatment; besarnya efek dari treatment bantuan diri sama besar dengan intervensi yang didampingi oleh terapis; secara umum dampak dari penggunaan intervensi bantuan diri yaitu sebesar 0.76 (sangat kuat) setelah treatment (posttreatrment) dan 0.53 pada tindak lanjut (Gould \& Clum, 1993).

Bergsma (2008) menjelaskan buku bantuan diri (psychological well-being) merupakan sebuah tindakan yang dilakukan untuk membantu atau memperbaiki diri sendiri tanpa bantuan orang lain. Membantu diri sendiri merupakan bentuk mengatasi masalah pribadi atau emosional seseorang tanpa bantuan dari tenaga profesional. Buku bantuan diri (psychological well-being) menyediakan catatan fenomenologis tentang gangguan perilaku dalam istilah sehari-hari, meningkatkan identifikasi dan empati, menghasilkan harapan dan wawasan, memberikan nasehat dan teknik yang jelas, menjelaskan strategi perawatan (treatment), dan merangkum temuan penelitian (Norcross, 2000; Pardeck, 1998).

Terdapat bukti bahwa membaca buku bantuan diri (psychological well-being) dengan masalah yang spesifik cenderung sangat membantu untuk orang-orang dengan masalah tertentu (Bergsma, 2008).

Penelitian menunjukkan bahwa sifat alami dari bacaan biblioterapeutik (yaitu, bacaan dan penarikan yang terarah), karakteristik relasional (yaitu, kemiripan karakter dengan pengalaman klien), dan pembawaan karakteri (yaitu, perendaman dan pelarian) adalah salah satu manfaat utama intervensi biblioterapi (Cohen, 1993). Penelitian terbaru yang dilakukan mengenai kegunaan buku bantuan diri (psychological well-being) menunjukkan bahwa mereka dapat meningkatkan kualitas terapi kognitif/perilaku. Misalnya, keuntungan dari biblioterapi kognitif yaitu kemudahan 
akses dan memberikan perawatan pendorong dengan membaca ulang buku tersebut, dengan $48 \%$ partisipan mengaku melakukan hal tersebut (Jamison \& Scogin, 1995).

Selain itu, buku bantuan diri (psychological well-being) memiliki korelasi positif dengan beberapa topik tertentu diantaranya adalah topik keluarga berkorelasi positif, intimimasi berkorelasi sangat positif, kesehatan jiwa berkorelasi sangat positif (Bergsma, 2008).

Campbell dan Smith (2003) mengemukakan Beberapa jenis hal yang perlu dipertimbangkan ketika akan memilih buku untuk bibiloterapi maka terdapat tiga hal yang perlu dipertimbangkan yaitu adjunctive versus integrative, nonfiction versus fiction, dan clinical use versus support/informational use.

\section{METODOLOGI}

Penelitian ini merupakan jenis penelitian dan pengembangan (Research and Development) dengan menggunakan model ADDIE. Penelitian dilakukan hanya sampai pada tahap analisis, desain, dan pengembangan, tanpa melakukan tahap implementasi dan evaluasi.

Populasi dalam penelitian ini adalah seluruh peserta didik SMA yang orangtuanya bercerai di DKI Jakarta. Sedangkan sampel yang digunakan adalah 27 peserta didik yang orangtuanya bercerai tingkat SMA di DKI Jakarta dan 2 orang guru bimbingan dan konseling.

Teknik atau cara pengumpulan data yang digunakan dalam penelitian ini yaitu (a) menyebarkan angket memalui google formulir dengan kriteria responden peserta didik SMA di Jakarta yang orangtuanya bercerai untuk asesmen kebutuhan, (b) melakukan wawancara dengan lima orang responden yang telah mengisi angket pada google formulir berkaitan dengan gambaran permasalahan secara lebih dalam dan masukan untuk pengembangan buku bantuan diri (c) melakukan wawancara dengan dua orang guru bimbingan dan konseling untuk mengggali informasi mengenai gambaran masalah anak yang orangtuanya bercerai serta teknik yang biasanya digunakan untuk menanganai mereka (d) menyebarkan angket evaluasi atau penilaian produk media buku bantuan diri untuk membantu remaja yang orangtuanya bercerai memelihara ikatan kelekatan paca perceraian kepada ahli medi, ahli materi, peserta didik, dan guru bimbingan dan konseling untuk mengetahui kelayakan produk yang sudah dikembangkan oleh peneliti.

\section{HASIL PENELITIAN}

Analisis. Berdasarkan studi pendahuluan yang peneliti lakukan didapatkan hasil sebagai berikut : (1) perceraian merupakan sebuah peristiwa yang dapat mengancam keamanan remaja. Perasaan aman dan tidak aman memberikan persepsi mengenai ketersediaan dan responsifitas figur kelekatan, (2) reaksi emosi dan perilaku yang muncul beragam yang merupakan cara untuk menjangkau figur kelekatan. Diantaranya adalah perasaan sedih, marah,kecewa,benci,malu, bahkan iri dan cemburu pada teman dengan keluarga yang tidak bercerai. Selain itu juga berpengaruh terhadap berbagai aspek kehidupan anak baik sosial, akademik, maupun pribadi, (3) responden juga tertarik dengan buku bantuan diri dan memiliki masukan (input) terhadap desain media.

Desain. Pada tahap ini, peneliti menyusun tujuan yang ingin dicapai dan membuat konten (isi) yang akan dimasukan ke dalam buku bantuan diri. Adapun yang dilakukan adalah melakukan inventarisasi tugas, menyebutkan tujuan kinerja, serta menghasilan strategi pengujian.

Pengembangan. Tahap ini peneliti melakukan pengembangan media. Adapaun hal yang dilakukan adalah menghasilkan konten, memilih atau mengembangkan media pendukung, mengembangkan petunjuk penggunaan produk, serta melakukan evaluasi formatif. Buku bantuan diri terdiri dari 226 halaman yang terbagi menjadi tujuh bagian (chapter). 
Penilaian terhadap buku bantuan diri ini dilakukan oleh ahli media oleh dosen teknologi pendidikan. Penilaian ahli materi oleh dosen bimbingan dan konseling. Penilaian pesserta didik kepada sepuluh orang, serta dua orang guru bimbingan dan konseling.

. Berdasarkan rumus perhitungan nilai rata-rata pada evaluasi formatif, maka didapatkan hasil sebagai berikut.

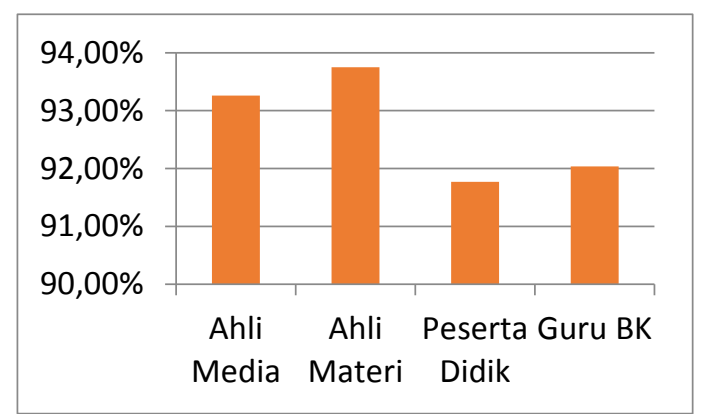

Tabel 1. Hasil evaluasi formatif

Kesimpulan dari hasil penilaian yang dilakukan oleh uji ahli media menunjukkan persentase sebesar 93,26\% yang berarti video tutorial penulisan lamaran kerja ini termasuk dalam kategori sangat baik dan berada pada kriteria layak.

Kesimpulan dari hasil penilaian yang dilakukan oleh uji ahli materi menunjukkan persentase sebesar $93,75 \%$ yang berarti video tutorial penulisan lamaran kerja ini termasuk dalam kategori sangat baik dan berada pada kriteria sangat layak.

Kesimpulan hasil penilaian dari uji coba peserta didik menunjukkan persentase sebanyak $91.77 \%$ yang berarti video tutorial penulisan lamaran kerja ini termasuk dalam kategori sangat baik dan berada pada kriteria sangat layak.

Kesimpulan hasil penilaian guru bimbingan dan konseling menunjukkan persentase sebanyak $92.04 \%$ yang berarti video tutorial penulisan lamaran kerja ini termasuk dalam kategori sangat baik dan berada pada kriteria sangat layak.

Peneliti menyadari bahwa dalam penelitian ini masih terdapat beberapa keterbatasan, antara lain : (1) bagian-bagian (Chapters) pada konten buku bantuan diri yang dikembangkan hanya membuat orang menyadari mengenai isu perceraian dan kelekatan yang bukan merupakan suatu urutan intervensi, (2) pada setiap bagian (chapter) hanya membantu peserta didik mengenali isu mengenai dirinya dengan istilah tertentu yang berkaitan dengan perceraian, (3) pada bagian pertama mengenai pandangan terhadap perceraian, bagian kedua mengenai terlibat dengan perasaan diri, bagian ketiga mengenai identifikasi dampak perceraian, bagian keempat mengenai mengekspresikan perasaan kepada orangtua, bagian kelima mengenai harapan yang aman, bagian keenam mengenai cara membuka jalur komunikasi dengan orangtua, pada bagian ketujuh mengenai refleksi diri terhadap perubahan yang didapatkan selama mengerjakan buku bantuan diri, (4) pengembangan media dibatasi sampai tahap pengembangan sehingga penilaian terhadap buku masih terbatas dan belum teruji keefektifannya secara lebih luas, (5) uji terbatas hanya 10 orang peserta didik dan dua orang guru BK, (6) pada penelitian ini, peneliti tidak melakukan uji coba pilot test, hal ini dikarenakan pilot test pada buku bantuan diri membutuhkan waktu yang cukup panjang.

\section{KESIMPULAN}

Berdasarkan hasil penelitian dan pengembangan tentang media buku bantuan diri memelihara ikatan kelekatan, dapat disimpulkan bahwa buku bantuan diri merupakan media yang dapat dikembangkan dalam memberikan bantuan terkait pemeliharaan ikatan kelekatan pasca perceraian. Pengembangan media buku bantuan diri untuk pengambilan memelihara ikatan kelekatan bagi peserta didik di DKI Jakarta telah memiliki komponen yang sangat baik.

Penelitian ini dilakukan dengan model Research and Development (Rnd) yang berbasis pada pengembangan dengan menggunakan metode ADDIE. Dalam penelitian ini, peneliti hanya melakukan tiga tahap yaitu analisis, desain dan 
pengembangan. Hal tersebut dikarenakan adanya keterbatasan waktu. Spesifikasi pada media ini dilengkapi dengan isi materi, ilustrasi gambar, font tulisan yang dapat menunjang penyampaian informasi melalui media ini.

Evaluasi yang dilakukan dalam penelitian ini adalah evaluasi formatif, yang dilakukan oleh ahli media, ahli konten, peserta didik dan guru bimbingan dan konseling. Berdasarkan evaluasi tersebut, menunjukkan bahwa tingkat validasi media $93.26 \%$, tingkat validasi konten mencapai 93.75\%, hasil uji coba peserta didik $91.77 \%$, dan penilaian guru BK yaitu $92.04 \%$

Saran. (1) dapat dilakukan penelitian lanjutan dapat yaitu menguji keefektifan buku bantuan diri yang telah dikembangkan, (2) Penelitian dapat dikembangkan pada tahap ADDIE selanjutnya yaitu implementasi dan evaluasi, (3) dalam pembuatan buku bantuan diri menggunakan intervensi yang secara teori dapat mengatasi isu perceraian, (4) setiap bagian (chapter) buku bantuan diri yang dikembangkan didasarkan pada urutan intervensi yang berkaitan dengan teori, (5) guru BK dapat memanfaatkan buku ini sebagai salah satu media untuk membantu peserta didik secara individual maupun kelompok dalam biblioterapi.

\section{DAFTAR PUSTAKA}

Adams, S. J., \& Pitre, N. L. (2000). Who Uses Bibliotherapy and Why? A Survey from an Underserviced Area. The Canadian Journal of Psychiatry, 45(7), 645-649. https://doi.org/10.1177/070674370004 500707

Ahiaoma, I. (2013). The psycho-social effect of parental separation and divorce on adolescents: Implications for counselling in Surulere Local Government Area of Lagos State. International Journal of Psychology and Counselling, 5(7), 162-168.

Ainsworth, M. D. S., \& Bell, S. M. (1970). Attachment, Exploration, and
Separation: Illustrated by the Behavior of One-Year-Olds in a Strange Situation. Child Development, 4l(1), 49. https://doi.org/10.2307/1127388

Ainsworth, M. D. S., Blehar, M. C., Waters, E., \& Wall, S. N. (2015).

Patterns of attachment: A psychological study of the strange situation. New York: Psychology Press.

Bergsma, A. (2008). Do self-help books help? Journal of Happiness Studies, 9(3), 341-360. https://doi.org/10.1007/s10902-0069041-2

Bowlby, J. (1973). Attachment and loss: Volume II: Separation, anxiety and anger. In Attachment and Loss: Volume II: Separation, Anxiety and Anger (pp. 1-429). London: The Hogarth Press and the Institute of Psycho-Analysis.

Bowlby, J. (1982). Attachment and loss: retrospect and prospect. American Journal of Orthopsychiatry, 52(4), 664.

Bretherton, I. (1990). Open communication and internal working models: Their role in the development of attachment relationships. In R. A. Thompson (Ed.), Current theory and research in motivation, Vol. 36. Nebraska Symposium on Motivation, 1988: Socioemotional development. University of Nebraska Press.

Campbell, L. F., \& Smith, T. P. (2003). Integrating self-help books into psychotherapy. Journal of Clinical Psychology, 59(2), 177-186. https://doi.org/10.1002/jclp.10140

Cohen, L. J. (1993). The Therapeutic Use of Reading: A Qualitative Study. Journal of Poetry Therapy Volume, 7 , 73-83.

Dublin City Council. (2011). Bibliotherapy: the power of words.

Gould, R. A., \& Clum, G. A. (1993). A meta-analysis of self-help treatment approaches. Clinical Psychology 
Review, 13(2), 169-186. https://doi.org/10.1016/02727358(93)90039-O

Harsanti, I., \& Verasari, D. G. (2013). Kenakalan pada Remaja yang Mengalami Perceraian Orangtua. Proceeding PESAT (Psikologi, Ekonomi, Sastra, Arsitektur \& Teknik Sipil), 71-77. Bandung.

Heinicke, C. M., \& Westheimer, I. (1966). Brief separations. International U. Press.

Jamison, C., \& Scogin, F. (1995). The outcome of cognitive bibliotherapy with depressed adults. Journal of Consulting and Clinical Psychology, 63(4), 644-650. https://doi.org/10.1037/0022006X.63.4.644

Johnson, S. M. (2002). Emotionally focused couple therapy with trauma survivors: Strengthening attachment bonds. New York: Guilford Press.

Kobak, R., Zajac, K., \& Madsen, S. D. (2016). Attachment disruptions, reparative nd psychopathology: theoretical and clinical implications. In J. Cassidy \& P. R. Shaver (Eds.), Handbook of attachment : theory, research and clinical applications (Vol. 3) (pp. 25-39). New York: The Guildford Press.

Kramer, P. A., \& Smith, G. G. (1998). Easing the pain of divorce through children's literature. Early Childhood Education Journal, 26(2), 89-94.

Malchiodi, C. A. (2015). Bibliotherapy recommendations. In C. A. Malchiodi (Ed.), Creative interventions with traumatized children. New York: The Guilford Press.

Mustonen, U., Huurre, T., Kiviruusu, O., Haukkala, A., \& Aro, H. (2011). Long-term impact of parental divorce on intimate relationship quality in adulthood and the mediating role of psychosocial resources. Journal of Family Psychology, 25(4), 615.

Ningrum, P. R. (2013). Perceraian orang tua dan penyesuaian diri remaja. Jurnal Psikologi, 1(1), 69-79.

Norcross, J. C. (2000). Here comes the selfhelp revolution in mental heath. Psychotherapy: Theory, Research, Practice, Training, 37(4), 370-377. https://doi.org/10.1037/00333204.37.4.370

Pardeck, J. T. (1998). Using books in clinical social work practice. Binghamton: The Hawthorne.

Perry, B. D. (2001). Bonding and attachment in maltreated children. The ChildTrauma Academy, 3, 1-17.

Prior, V., \& Glaser, D. (2006). Understanding attachment and attachment disorders: Theory, evidence and practice. London: Jessica Kingsley Publishers.

Rice, K. G. (1990). Attachment in adolescence: A narrative and metaanalytic review. Journal of Youth and Adolescence, 19(5), 511-538.

Vaughn, B. E., \& Bost, K. K. (2016). Attachment and temperament as intersecting developmental products and interacting developmental contexts throughout infancy and childhood. In Jude Cassidy \& P. R. Shaver (Eds.), Handbook of attachment: Theory, research, and clinical applications (3rd ed., pp. 202-222). New York: The Guilford Press.

Venta, A., Shmueli-Goetz, Y., \& Sharp, C. (2014). Assessing attachment in adolescence: A psychometric study of the Child Attachment Interview. Psychological Assessment, 26(1), 238.

Wallerstein, J. S., \& Lewis, J. M. (2004). The Unexpected Legacy of Divorce: Report of a 25-Year Study. Psychoanalytic Psychology, 21(3), 353. 


\section{Lampiran}

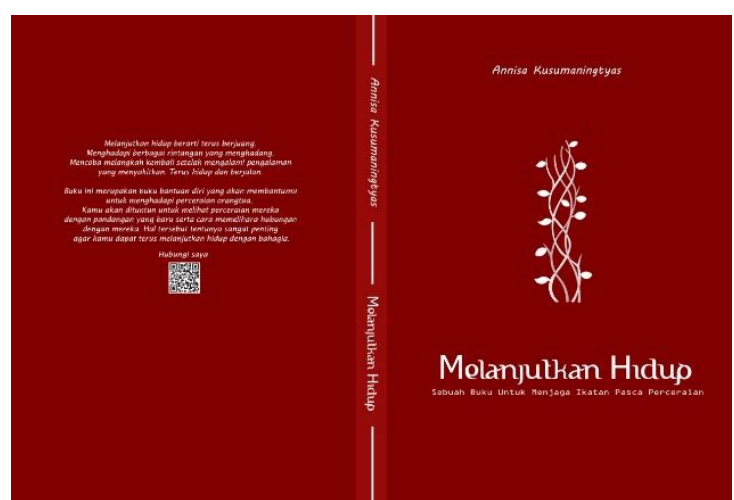

Sampul Buku
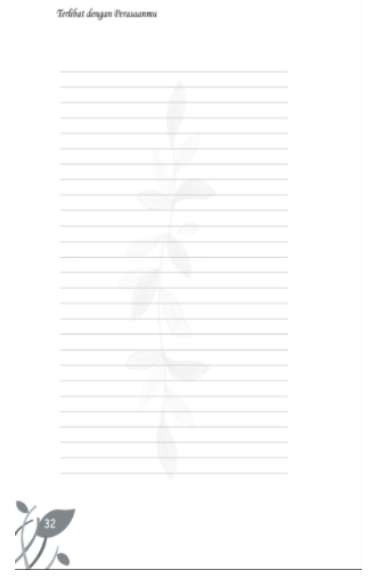

\section{Lembar Tugas}

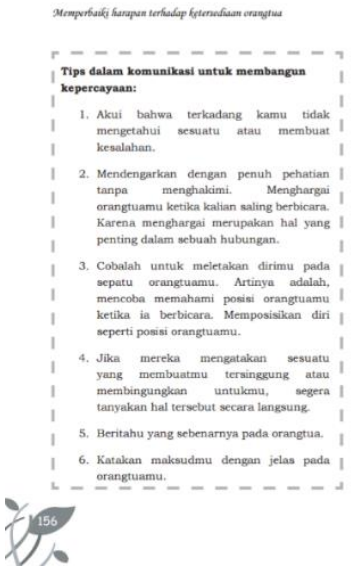

Kotak Tips

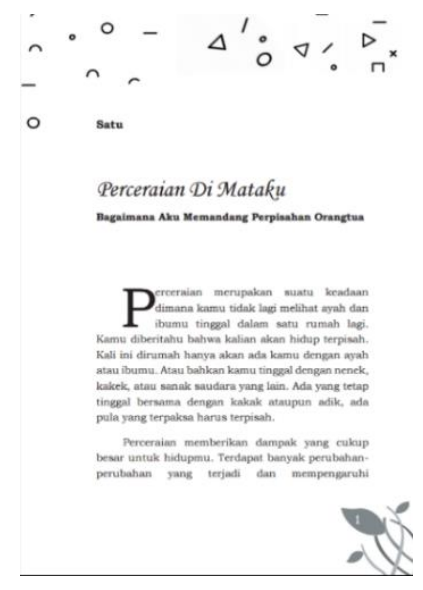

Awal Bab

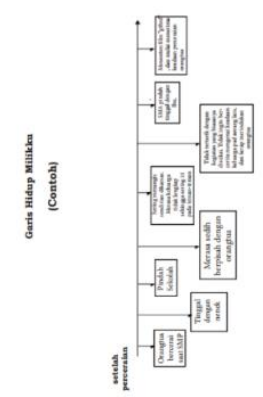

\section{Bagan}

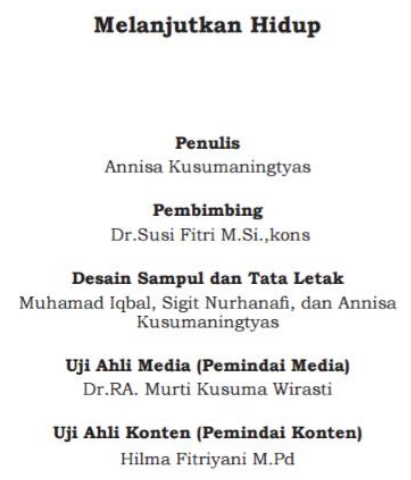

Identitas Buku 